\title{
AN APPROACH TO JOHN WITTE ON THE REFORMATION OF RIGHTS AND RELIGION
}

\author{
Alexander KOKOBILI, \\ Doctoral Researcher in Systematic and Practical Theology \\ Department of Theological Ethics, Evangelical Theological Faculty \\ Charles University, Prague, \\ CZECH REPUBLIC \\ Email: alexkokobili@yahoo.com
}

\begin{abstract}
This article focuses on the insight of Professor John Witte Jr., (b. 1959) in relation to human rights and religion. Witte has a distinctive theological path with vast scholarly works in connection to ethics, law and human rights at the Emory University in Atlanta. Although the origin of human rights has been interpreted differently by many authors in the past. However, Witte's exposure to the emergence of modern human rights gives attention to its religious roots and the establishment of the 1948 Universal Declaration of Human Rights. The concept of religious freedom and individual rights was paramount in Calvinism, while the Papacy also tried in the reformation of its Canon Law. The 1948 United Nations Human Rights Charter came at a time when the project of human rights became inevitable after the mass atrocities caused by World War II. This article will, therefore, give a unique understanding of the emergence of modern human rights through a religious dialogue.
\end{abstract}

Keywords: Calvinism; Human Rights; Witte, Religious Freedom; Canon Law;

\section{INTRODUCTION}

The emergence of modern human rights has been linked to numerous historical events such as the 1780 French Declaration Rights of Man and Citizen, eighteenth-nineteenth century philosophical Enlightenment Era, the Great Awakening; and other political or sociocultural happenings across various societies. Also, the United Nations Universal Declaration of Human Rights was established to take-up the responsibility of the world's human rights umpire in 1948. For Witte, human rights narratives are best approached from their religious roots due to its composition of norms such as liberty, equality, shared values of life, respect, liberty, and property. ${ }^{1}$ To separate religion from the people is to separate them from belief and moral conscience because of its effects their way of life in the community.

Religion is not just about belief in a supreme being, but also what that belief means to the people. For example, the Bible has a lot of covenants and laws which guided the way of life of the Israelites and these early moral creeds such as the Ten Commandment were a guide on the rights and freedom of the people. Other religions such as Islam, Hindu, and Buddhism have their various moral elements ethical in their books such as Koran, Vedas, and Tripitaka, on religious expressions and other aspects of life. Christianity, unlike these

\footnotetext{
${ }^{1}$ John Witte, A Dickensian Era of Religious Rights 2001, Pp 713.
} 
religions, has been at the forefront of religious revolutions in past centuries and most especially the sixteenth Calvinist Protestant Reformation.

\section{CALVINISM AND THE REFORMATION OF RIGHTS}

For Witte, the sixteenth-century era of the Calvinist Reformation on religious rights implanted a foundation for the expression of freedom and respect of the law for centuries in Europe. He explained, "The Calvinist Reformation congregationalized the faith by introducing the notion of rule by a democratically elected consistory of pastors, elders, and deacons. In John Calvin's days, the Geneva consistory was still appointed and held broad personal and subject matter jurisdiction over all members of the city. By the seventeenth century, however, most Calvinist communities in Europe and North America reduced the consistory to an elected, representative system of government within each church. These consistories featured separation of the offices of preaching, discipline, and charity, as well as a fluid, dialogical form of religious polity and policing centered around collective worship and the congregational meeting. The Protestant Reformation also broke the primacy of corporate Christianity and placed a new emphasis on the role of the individual believer in the economy of salvation. The Protestant Reformation did not invent the individual, as too many exuberant commentators still maintain. Rather, the sixteenth-century Protestant reformers, more than their Catholic contemporaries, gave new emphasis to the (religious) rights and liberties of individuals at both religious law and civil law". ${ }^{2}$ Calvin's Protestant approach focused on religious rights relating to moral law and also aspects of positive law in recognition to the civil government. This concept meant that the people must be free to make decisions as guided by God's moral law and likewise exercise their liberty before the civil authority. Many of early Protestant theologians such as Theodore Beza (1519-1605), John Hooper (1495-1555), John Knox (1513-1572), etc., all of whom elaborated on Calvin's ideas of religious and specific rights on individuals across Europe.

Early Calvinism portrayed the doctrine of God as the originator of the law and humans are governed by Godly ordinances such as the Ten Commandments which was given for man's moral consciences. This did not dispute the role of magistrates and rulers who were also considered as given their rights as rulers over the subjects by God. Witte explained, "These Protestant teachings helped to inspire many of the early modern revolutions fought in the name of human rights and democracy. They were the driving ideological forces behind the revolts of the French Huguenots, Dutch pietists, and Scottish Presbyterians against their monarchical oppressors in the later sixteenth and seventeenth centuries. They were critical weapons in the arsenal of the revolutionaries in England, America, and France. They were important sources of the great age of democratic construction in the later eighteenth and nineteenth-century America and Western Europe. In this century, Protestant ideas of human rights and democracy helped to drive the constitutional reformation of Europe in the postWar period, as well as many of the human rights and democratic movements against colonial autocracy in Africa and fascist revival in Latin America". ${ }^{3}$ This means, religious beliefs are part of what makes up communal values and structure, upon which the community is governed by sets of formulated creeds. To deny the people of their religious the orientation means to restrict their ability to express their moral conscience and thoughts.

\footnotetext{
${ }^{2}$ John Witte, A Dickensian Era of Religious Rights, 2001, Pp 734.

${ }^{3}$ Ibid, Pp. 737.
} 
Religion is not the law, but it guides the actions of people in the concept of the law; giving moral guidance of what is right or wrong. Witte explained, "Religions inevitably help to define the meanings and measures of shame and regret, restraint and respect, responsibility and restitution that a human rights regime presupposes. Religions must thus be seen as indispensable allies in the struggle for modern human rights. To exclude them from the struggle is impossible, indeed catastrophic. To include them, by enlisting their unique resources and protecting their unique rights, is vital to enhancing the regime of human rights and to ease some of the worst paradoxes that currently exist". ${ }^{4}$ Thus, the era of modern human rights promoted the rights to freedom of religion and other forms of association which have proven resilient in the struggled against all form of injustice in society. This resulted in the formation of Non-Governmental Organizations (NGOs), Civil Rights movements in Euro-American history, the formation of Christian Democratic Parties in Europe, new congregations of Evangelical and Free Churches across the world, and numerous cultural, scientific or educational organizations, etc.

\section{CALVINISM AND NEW ENGLAND CONSTITUTIONAL RIGHTS}

The impact of Calvinism was not just about religious freedom, but on constitutional documents in early America such as the 1647 Laws and Liberties of Massachusetts, the 1658 Puritan Laws, and Liberties, 1780 Massachusetts Constitution amongst others. Also, with the introduction of democracy in America in 1776, there has been a huge encouragement on the right to commerce and property in eighteenth and nineteenth-century Europe and America. The Puritans in early America didn't completely shift their focus from the moral aspects of the society but also craved for a society where people can access to constitutional documents consisting of all forms of rights such as commerce, property, gender equality, and women emancipation, etc. For instance, Max Weber's thesis of 1905 "The Protestant Ethic and the Spirit of Capitalism" acknowledged Protestant-Puritan idea as haven spearheaded the course of modern capitalism. It affirmed, "taken together, these represent a mixture of necessary and precipitating conditions which, in conjunction with the moral energy of the Puritans, brought about the rise of modern western capitalism. But if Puritanism provided that vital spark igniting the sequence of change creating industrial capitalism, the latter order, once established, eradicates the specifically religious elements in the ethic which helped to produce it". ${ }^{5}$ The rights to commerce or property mean people encourage wealth creation and enabled the government to generate revenue from taxes used for the welfare of the state.

\section{THE PAPAL REVOLUTION}

For Witte, apart from the influence of the Calvinism on the reformation of rights, it is important to mention that the Roman Catholic Church had attempted to reform its concept of rights and Canon Law, in past centuries. The First Papal Revolution of Pope Gregory VII (1073-1085) sought to restore the rights of the church and the separation of the piety from the civil rule in line with western values. ${ }^{6}$ The actualization of this Papal Revolution failed due to policies of the papacy and rigid structure of the Canon Law. The Council of Trent 15451563 didn't also prove successful due to its focus to challenge the revolution of Protestantism on its doctrine rather than the reformation of rights. Also, the Catholic Canon Law in the

\footnotetext{
${ }^{4}$ John Witte, A Dickensian Era of Religious Rights, 2001, Pp. 713.

${ }^{5}$ Max Weber, The Protestant Ethic and the Spirit of Capitalism 1905, translated to English by Talcott Persons 1930. Library of Congress Cataloging in Publication Data, (Introduction) Pp. XVII.

${ }^{6}$ John Witte, A Dickensian Era of Religious Rights, 2001, Pp. 727.
} 
medieval era focused more on rights of clergies, exemptions of the church from taxes and levies, church symbols and icons, the Eucharist, and all forms of privileges associated with nobility, etc. ${ }^{7}$ The focus of the Canon Law did not give much attention to the individual rights of the people in the relating to personal religious interpretation as it was considered as a rebellion against the Vatican in the Case of Martin Luther, John Calvin.

The Second Vatican Council (1962-1965), unlike the previous councils, focused on the theological attitude of the church in respect to the democratic rights of members of the church. ${ }^{8}$ Witte believed that the Second Vatican Council endorsement of human rights was to allow the church and people to have the understanding that all human were created with intelligence to make choices and rights. ${ }^{9}$ Witte explained, "such rights include the right to life and adequate standards of living, to moral and cultural values, to religious activities, to assembly and association, to marriage and family life, and to various social, political, and economic benefits and opportunities. The Church emphasized the religious rights of conscience, worship, assembly, and education, calling them the "first rights" of any civic order. The Church also stressed the need to balance individual and associational rights, particularly those involving the church, family, and school. Governments everywhere were encouraged to create conditions conducive to the realization and protection of these "inviolable rights" and encouraged to root out every type of discrimination, whether social or cultural, whether based on sex, race, color, social distinction, language, or religion". ${ }^{10}$

I believe the focus of these reforms was a great improvement from previous attempts of the Vatican with a focus on so many aspects of rights. It also admonished the government to protect the unhindered rights of persons but, did not purely distance the Church from the State based on the political might of the Vatican. Also, the council also gave rights to the people to gather for worship or express their conscience but did not go in-depth on Biblical moral law or the duties of the priest within the church which were more controlled by the Papacy. The Roman Catholic Reformation of rights in Witte's approach can be commended for its human rights efforts due to the spread of its influence in the 1970s in countries such as Ukraine, Poland, Brazil, the Philippines, Hungary, Chile, Central America, and the Czech Republic, and it helped redefined the focus on rights and freedom by the Vatican. ${ }^{11}$ Similarly, Catholic human rights reforms by its structure were to preserve the unity of the Church with the alliance to the Vatican. Also, the testimony of Jan Karski a Polish Roman Catholic to President Franklin Roosevelt in 1943 on the killings of Jews during the Holocaust, encouraged western countries to focus more on restoring human dignity after the gross violation of human rights during World War II.

\section{THE 1948 UNIVERSAL DECLARATION OF HUMAN RIGHTS}

The establishment of the 1948 United Nations Universal Declaration was signed in Paris after the atrocities of the First and Second World Wars. This brought a new era to embrace the project of restoring human dignity after the death of millions of people in the wars. The Second World War was characterized by the biggest holocaust in human history with the killings of Jews and great atrocities committed against humanity by the Nazi army. The project of human rights now needs a collaborative effort by both the religious and other

\footnotetext{
${ }^{7}$ Ibid, Pp. 727.

${ }^{8}$ John Witte, A Dickensian Era of Religious Rights, 2001, Pp. 729.

${ }^{9}$ Ibid, Pp. 729.

${ }^{10}$ John Witte, A Dickensian Era of Religious Rights 2001, Pp. 730-731.

${ }^{11}$ Ibid, Pp. 731.
} 
social institutions such as; the civil parliament and the 1948 United Nations Human Rights Charter to prevent a repeat of the calamities the World Wars. For instance, the role of Eleanor Roosevelt (the wife of President Franklin Roosevelt) a Protestant who chaired the 1948 United Nations (UN) was significant; because she was a woman who worked with numerous people of various religions and thoughts on the Project. The UN Human Rights Charter embraced absolute freedom of all persons in Article I of the Declaration, "All human beings are born free and equal in dignity and rights. They are endowed with reason and conscience and should act towards one another in a spirit of brotherhood". ${ }^{12}$ The purpose of this acknowledgment of basic freedom for all is aimed at preventing a repeat of gross violations of human rights of the World War II and also to promote equal access to rights, thoughts and reason, religious freedom of all citizens of the world.

The 1948 Universal Declaration on Human Rights influenced other conventions on human rights which sprung up at different times in the twentieth century. Some of which includes: the 1966 International Covenant on Civil and Political, the 1981 United Nations Declaration on the Elimination of All Forms of Intolerance and of Discrimination Based on Religion or Belief, and the 1993 Vienna Declaration and Programme of Action on human rights. For instance, Witte pointed out that the 1966 Covenant on Civil and Political Rights also supported freedom of religion, thoughts and moral education for children in the same repeat text as Article 18 of the 1948 Human Rights Charter, "Everyone shall have the right to freedom of thought, conscience, and religion. This right shall include freedom to have or to adopt a religion or belief of his choice, and freedom, either individually or in community with others and in public or private, to manifest his religion or belief in worship, observance, practice, and teaching. No one shall be subject to coercion which would impair his freedom to have or to adopt a religion or belief of his choice. Freedom to manifest one's religion or beliefs may be subject only to such limitations as are prescribed by law and are necessary to protect public safety, order, health, or morals or the fundamental rights and freedoms of others. The States Parties to the present Covenant undertake to have respect for the liberty of parents and, when applicable, legal guardians to ensure the religious and moral education of their children in conformity with their own convictions". ${ }^{13}$

Freedom of religion, in this case, can be expressed as a personal right of a person or group of persons without compulsion by another. Parents could guide their children in religious beliefs or convictions as long as there are children and this means the children could make independent decisions in their adulthood. The idea of religion, in this case, is opened to all forms of religions in the community which could be expressed at will. It is important to note that the United Nations Charter does not give special consideration for countries with a national religion to disrespect the religious freedom of other people. For instance, countries were a majority of its populace are Christians, Muslims, Buddhist, Hindu, etc., are expected to show consideration to people of other religions in their country. This which means a nation should be able to accommodate people of diverse religions as a way of showing respect to individuals of different religious rights beliefs.

Also, the 1981 Human Rights Declaration recognizes freedom in every sphere of human life in its Article I, which includes non-discrimination of people based on gender or

\footnotetext{
${ }^{12}$ The 1948 United Nations Universal Declaration of Human Rights, Article 1.

${ }^{13}$ John Witte, A Dickensian Era of Religious Rights 2001, Pp. 747.

See also, International Covenant on Civil and Political Rights. Adopted by the General Assembly of the United Nations on 19 December 1966 Article 18, The United Nations Universal Declaration on Human Rights, Article 18.
} 
socio-economic status in the society. Similarly, the 1993 Convention focused to eliminate racism, xenophobia and all forms of intolerance against people. The Convention's Adoption 17 also gives rights to religious expression in any language of choice and the Adoption 22 kicked against violence on those expressing their religious views. Similarly, other conventions which were drafted to adopt the articles of 1948 Human Rights Charter on religious freedom and other rights includes: the European Convention for the Protection of Human Rights and Fundamental Freedoms (1950), the American Convention on Human Rights (1969), and the African Charter on Human and People's Rights (1981) etc. ${ }^{14}$

\section{CONCLUSION}

The importance of human rights in this democratic dispensation in most societies today have become a huge revolving task despite the historical influence of religion over the years. This is because religion itself may have tried in its reformation agenda, but still faces challenges especially in cases that concern human rights violations. For instance, Witte believed that socio-religious proselytizing trends should focus on tolerance of people of other beliefs or religions, rather than aggressive faith conversion. ${ }^{15} \mathrm{I}$ believe this will enable people to decide their religious beliefs and promote the freedom of conscience in accordance with the articles of the 1948 Human Rights Charter. The Golden Rule in the Bible also admonishes all Christians to be tolerant with others as to themselves; "Therefore, whatever you want men to do to you, do also to them, for this is the Law and the Prophets" (Mathew $7: 12$ ). The respect of religious beliefs is not limited to the same religion, but to all people of diverse religions in other for it to be reciprocal. When tolerance and respect fail to exist in the community, abuse or infringement of the rights and freedom of others are inevitable. Also, some forms of religious intolerance have also been linked by ugly events of human history, apart from the usual violations of human rights which are common to tyrannical governments. For instance, the past centuries have recorded some major conflicts linked to religion such as The French Religious War 1562-1598, Bosnian War 1992-1995, IsraeliPalestine conflict 1948-date, The Northern Ireland Conflicts 1968-1998 and other conflicts in Sudan, Republic of South Sudan, Central African Republic, Neymar, Nigeria, etc. To this, Witte explained, "In some communities, such as the former Yugoslavia, local religious and ethnic rivals, previously kept at bay by a common oppressor, have converted their new liberties into licenses to renew ancient hostilities, with catastrophic results. In other communities, such as Sudan and Rwanda, ethnic nationalism and religious extremism have conspired to bring violent dislocation or death to hundreds of rival religious believers each year, and persecution, false imprisonment, forced starvation, and savage abuses to thousands of others. In other communities, most notably in North America and Western Europe, political secularism and nationalism have combined to threaten a sort of civil denial and death to a number of believers, particularly "sects" and "cults" of high religious temperature or of low cultural conformity. In still other communities, from Asia to the Middle East, Christians, Jews, and Muslims, when in minority contexts, have faced sharply increased restrictions, repression, and, sometimes, martyrdom". ${ }^{16}$ This does not contradict the role of religion on human rights project on fairness, equality and the respect of human dignity, but shows that there is still a lot of work to be done on protecting the project of human rights.

\footnotetext{
14 John Witte, A Dickensian Era of Religious Rights 2001, Pp. 753.

${ }^{15}$ Ibid, Pp.765.

${ }^{16}$ John Witte, A Dickensian Era of Religious Rights 2001, Pp.710.
} 
Religious freedom should be considered as the foundation for all other forms of freedom due to its role in society and the attachment of humans to some form of belief. For instance, the notion of love as a moral law in the Decalogue (Holy Bible, Leviticus 19:18), "Thou shalt not avenge, nor bear any grudge against the children of thy people, but thou shalt love thy neighbor as thyself: I Am the Lord", has propelled Christianity to respect the rights of others relating to religious freedom and other forms of rights which were also a sticking point in early Calvinism. On the other hand, the rise of Islamic religious extremist groups such the Islamic States, Al-Shabaab, Boko Haram, and other Jihadist groups may also have placed Islam in a high spotlight of intolerance when compared to other religions of the world. Despite these ups and downs, religious freedom could mean religious harmony and tolerance as a way of respecting all other rights persons regardless of their religion. It is also important to mention the role of the Parliament of the World's Religions cannot be ignored since the inception in 1893 in Chicago, due to its positive attitude on religious freedom and tolerance till date. For instance, Gaston Bonet-Maury was a notable Protestant and pastor who was part of the founding members of the Congress. He represented the whole of Christianity; while other religions such as Judaism, Buddhism, Islam, amongst others, were all represented separately.

\section{BIBLIOGRAPHY:}

[1] International Covenant on Civil and Political Rights. Adopted by the General Assembly of the United Nations on 19 December 1966 Article 18.

[2] John Witte Jr., A Dickensian Era of Religious Rights: An Update on Religious Human Rights in Global Perspective, Vol 42, Issue 3/5, William and Mary Law Review, 2001, Pp. 710, 713, 727,729, 730,731, 734, 737, 747,753,765.

[3] Max Weber, The Protestant Ethic and the Spirit of Capitalism 1905, translated to English by Talcott Persons 1930. Library of Congress Cataloging in Publication Data, (Introduction) Pp. XVII.

[4] The 1948 United Nations Universal Declaration on Human Rights, Article 1, 18.

[5] The Holy Bible (NKJV): Mathew 7:12 "Therefore, whatever you want men to do to you, do also to them, forth is the Law and the Prophets., Leviticus 19:18 "You shall not take vengeance, nor bear any grudge against the children of your people, but you shall love your neighbor as yourself: I am the LORD". 